\title{
PENCEGAHAN DAN PERLINDUNGAN ANAK BERBASIS GAMPONG DI ACEH
}

\author{
Abidin Nurdin \\ Universitas Malikussaleh, Aceh, Indonesia \\ E-mail: abidin_majene@yahoo.co.id
}

\begin{abstract}
This paper discussed the prevention and protection of village-based ABH with the Adat approach in Aceh. The number of $A B H$ continues to grow which is caused by factors, the environment, wrong students, families are not harmonious, the lack of religious education. Not only in Indonesia, but also in Japan, the Philippines, Malaysia and Bangladesh formal legal processes have been left to be replaced by non-formal or diversion. However, the problem is the community's readiness and the responsibilities of parents in providing prevention and protection for $A B H$. In Aceh with traditional power which is thick with religious values it is able to provide prevention and protection even rehabilitation to village-based $A B H$. Some villages in Aceh have succeeded in making reusam gampong (village regulations) that put forward aspects of prevention and protection as well as strengthening traditional institutions (keuchik, tuha peut and teungku imum) and the role of parents. Sanctions given that are educational for example, cleaning meunasah, adhan for some time, memorizing some surahs in the Koran.
\end{abstract}

Keywords: gender mainstreaming; pesantren education; woman

Abstrak. Tulisan ini membahas tentang pencegahan dan perlindungan ABH berbasis gampong dengan pendekatan Adat di Aceh. Jumlah ABH terus bertambah yang disebabkan oleh faktor, lingkungan, salah didik, keluarga tidak harmonis, minimnya pendidikan agama. Saat ini bukan saja di Indonesia, tetapi juga di Jepang, Filipina, Malaysia dan Bangladesh proses hukum formal mulai ditinggal diganti dengan non formal atau diversi. Namun demikian yang jadi masalah adalah kesiapan masyarakat dan tanggung jawab orang tua dalam memberikan pencegahan dan perlindungan terhadap $\mathrm{ABH}$. Di Aceh dengan kekuatan adat yang kental dengan nilai-nilai agama mampu memberikan pencegahan dan perlindungan bahkan rehabilitasi pada $\mathrm{ABH}$ yang berbasis gampong. Beberapa gampong di Aceh telah berhasil membuat reusam gampong (peraturan desa) yang mengedepankan aspek pencegahan dan perlindungan serta penguatan lembaga adat (keuchik, tuha peut dan teungku imum) serta peran orang tua. Sanksi yang diberikan yang bersifat mendidik misalnya, membersihkan meunasah, azan dalam beberapa waktu, menghafal beberapa surah dalam al-Quran.

Kata Kunci: pengarusutamaan gender; pendidikan pesantren; perempuan

Permalink/DOI: https://doi.org/10.15408/harkat.v14i2.12813 


\section{Pendahuluan}

Di Indonesia, Anak yang Berhadapan dengan Hukum $(\mathrm{ABH})$ sudah menjadi permasalahan yang serius, karena dari tahun ke tahun jumlahnya terus meningkat. Mereka diajukan ke pengadilan atas tuduhan kejahatan ringan seperti pencurian, tanpa dukungan sama sekali dari pihak manapun, bahkan sembilan dari sepuluh anak tersebut akhirnya dipenjarakan di rumah tahanan. Jumlah anak yang berada di lembaga penahanan dan lembaga pemasyarakatan pada tahun 2011 berjumlah 6.141, tahun 2012 berjumlah 5.226 dan tahun 2013 berjumlah 4.953 (Kemenkumham, 2013). Tahun selanjutnya, populasi ABH kembali naik mencapai 8.394 orang, sebagian besar (70.2\%) dari anak-anak tersebut ditahan bersama para tahanan dan/atau narapidana dewasa (Kementerian Sosial, 2015). Faktor yang menyebabkan anak terjerumus dalam $\mathrm{ABH}$, yaitu kemiskinan menempati urutan tertinggi yaitu $29.35 \%$ disusul oleh faktor lingkungan sebanyak $18.07 \%$, salah didik sebesar $11.3 \%$, keluarga tidak harmonis sebesar $8.9 \%$ dan minimnya pendidikan agama hanya $7.28 \%$ yang memicu terjadinya tindak pidana oleh anak (Kementerian Sosial, 2015).

Bahkan lebih miris lagi adalah anak (khususnya anak perempuan) yang diperdagangkan dan dilacurkan di salah satu Kota Besar misalnya Surabaya. Laporan Tim ESKA Surabaya (Eksploitasi Seksual Komersial Anak) (2009), bahwa anak-anak yang dilacurkan di kota Surabaya, sebagian besar berasal dari keluarga miskin (38\%), selanjutnya berasal dari keluarga broken home (keluarga yang orang tuanya bercerai) (23\%) dan juga berasal dari keluarga pada umumnya sebanyak $6 \%$. Dengan berbagai alasan di antaranya pergaulan bebas ( 24 $\%)$, korban trafficking (21 \%), himpitan ekonomi (14\%) dan korban kekerasan dalam rumah tangga (9 \%). Studi tersebut menunjukkan bahwa alasan kemiskinan dan bujuk rayu calo menjadi penyebab utama anak-anak terlibat dalam dunia pelacuran (Wismayanti, 2013: 93).

Menurut UU tentang Sistem Peradilan Anak bahwa $\mathrm{ABH}$ adalah anak yang berkonflik dengan hukum, anak yang menjadi korban tindak pidana, dan anak yang menjadi saksi tindak pidana. Anak yang berkonflik dengan hukum yang selanjutnya disebut anak adalah anak yang telah berumur 12 (dua belas) tahun, tetapi belum berumur 18 (delapan belas) tahun yang diduga melakukan tindak pidana. Anak yang menjadi korban tindak pidana yang selanjutnya disebut Anak Korban adalah anak yang belum berumur 18 tahun yang mengalami penderitaan fisik, mental, dan/atau kerugian ekonomi yang disebabkan oleh tindak pidana. Sedangkan anak yang menjadi saksi tindak pidana yang selanjutnya disebut Anak Saksi adalah anak yang belum berumur 18 (delapan belas) tahun yang dapat memberikan keterangan guna kepentingan penyidikan, penuntutan, dan pemeriksaan di sidang pengadilan tentang suatu perkara pidana yang didengar, dilihat, dan/atau dialaminya sendiri (UU No. 11, 2012).

Sebagai perbandingan di Jepang sejak tahun 1974 sudah dibuat aturan tentang anak yang melakukan pelanggaran hukum. Setiap anak (shoonem) berumur 14-20 tahun yang melakukan kejahatan akan ditetapkan undangundang kesejahteraan anak, antara lain yaitu; 1) Tindakan Perlindungan (Menyerahkan anak kepada Sekolah Pendidikan Anak; Menyerahkan kepada Panti Pelatihan dan Latihan Anak; Menyerahkan anak kepada masyarakat dengan pengawasan dan bimbingan oleh pekerja sosial (pengawas sosial, probation); 2) Menyerahkan kembali ke kejaksaan, merupakan perkara yang akan ditangani dengan acara pidana yang sama sebagaimana perkara orang dewasa; 3) Menyerahkan ke Gubernur atau Ketua Pusat 
Bimbingan Anak, merupakan cara mensejahterakan anak (Tatsuya Ota, 1999; 111).

Di Malaysia penanganan anak yang berhadapan dengan hukum berdasarkan The Child Act 2001 adalah anak 14-18 tahun mirip dengan Indonesia. Namun di negeri jiran ini tidak mengenal diversi tetapi mediasi dan program pembinaan anak yang cukup ketat. Misalnya, ada program Malaysia care, character building dan integrity school. Malaysia care menyelenggarakan bimbingan agama, kelas musik dan character building (pembangunan karakter). Demikian pula integrity school dan program-program lain sangat diapresiasi baik oleh anak-anaknya maupun petugas penjaranya. Interaksi yang lebih banyak dengan orang di luar institusi berpengaruh positif pada perkembangan perilaku anak. Program-program yang diberikan sangat bermanfaat bagi proses rehabilitasi anak dan mengurangi kemungkinan pengulangan tindak pidana (Aprilianda, 2014: 78).

Di Filipina kategori anak yang melakukan kejahatan atau pelanggaran hukum 12-15 tahun. Menariknya hampir setiap Desa (Barangay) mempunyai tempat penitipan anak di Filipina ada 42.000 Desa. Sebagai contoh Barangay Batasan Hills dilengkapi 8 (delapan) tempat Penitipan Anak yang dibiayai Pemerintah; 22 (dua puluh dua) Tempat Penitipan Anak yang dibiayai pihak swasta. Tenaga pekerja yang ditugaskan pada tempat penitipan anak tersebut digaji oleh Negara (dengan anggaran yang tidak terlalu tinggi). Dalam Sistem Peradilan Pidana Anak (SPPA) di Filipina merupakan komponen penting dalam perencanaan diversi pada tataran Punong (kepala Desa) sedangkan Dewan Barangay yang dipimpin oleh seorang Kapten yang memiliki kewenangan mendamaikan (Aprilianda, 2014: 86).

Selain itu, di Negara Asia Selatan, misalnya Bangladesh masalah kekerasan terhadap
Anak dalam rumah tangga, eksploitasi anak dan berbagai masalah keluarga lainnya diselesaikan lembaga Shalish. Umumnya Shalish diartikan sebagai mediasi di dalam masyarakat Bangladesh. Lembaga tradisional ini ada pada sebagian masyarakat Bangladesh, yang memiliki nilai-nilai keadilan Restorative dalan bentuk metode Community-Based. Di mana terhadap perkara pidana diselesaikan melalui mekanisme di luar proses pengadilan (jalur Informal), dengan menggunakan mekanisme panel kecil dengan bantuan tokoh-tokoh lokal yang berpengaruh dalam membantu menyelesaikan perselisihan anggota masyarakat dan atau memberikan sanksi kepada mereka (hal ini merujuk dari model panel itu sendiri) (Khair, et.al, 2000: 8-9, dan Iswara, 2013: 66).

Pengalaman di beberapa Negara tersebut di atas menunjukkan adanya kesadaran bahwa dalam konteks $\mathrm{ABH}$ perlu adanya pendekatan hukum yang khusus, tidak dapat disamakan dengan orang dewasa. Sementara itu, hal yang perlu dikedepankan adalah aspek pencegahan dan perlindungan terhadap ABH. Program pencegahan diarahkan kepada kelompok anak dan masyarakat yang karena kondisi dan situasinya, membuat mereka menjadi rentan untuk menghadapi konflik dengan hukum. Pencegahan dibuat untuk menjauhkan anak dari kemungkinan berhadapan dengan hukum, memperbaiki kualitas perlindungan dan pengasuhan anak di dalam keluarga (Kemensos, 2012: 7). Sedangkan perlindungan anak adalah segala kegiatan untuk menjamin dan melindungi Anak dan hak-haknya agar dapat hidup, tumbuh, berkembang, dan berpartisipasi secara optimal sesuai dengan harkat dan martabat kemanusiaan, serta mendapat perlindungan dari kekerasan dan diskriminasi (Pasal 1, UU Perlinduangan Anak, 2014).

Mengacu pada hal tersebut di atas, maka kajian ini akan membahas tentang pencegahan dan perlindungan anak berbasis gampong (desa) 
di Aceh. Studi ini menjadi cukup penting sebab aspek pencegahan dan perlindungan anak selama sering diabaikan. Selain itu, kelompok yang paling berperan dan bertanggung jawab sesudah berlakunya UU sistem peradilan anak tahun 2012 adalah masyarakat dan orang tua. Masyarakat Aceh memiliki karakteristik yang kuat dengan nilai-nilai agama dan adat sehingga proses pencegahan, perlindungan bahkan rehabilitasi $\mathrm{ABH}$ tetap eksis yang kuat secara aplikatif.

\section{Kajian Teoritis tentang Perlindungan $\mathrm{ABH}$}

Kajian tentang Anak Berkonflik dengan Hukum telah dilakukan oleh beberapa peneliti misalnya; Meri Ganti (2012) meneliti tentang peran pekerja sosial Kementerian Sosial Republik Indonesia dalam Penerapan Restorative Justice bagi $\mathrm{ABH}$ yang dirujuk ke Panti Sosial di Jakarta. Kajian ini membahas penyelesaian kasus $\mathrm{ABH}$ di luar pengadilan atau restorative justice dalam istilah lain juga disebut non litigasi. Menurutnya pekerja sosial sudah cukup berperan, dalam dua aspek, yaitu mekanisme penyelesaian kasus dan reintegrasi $\mathrm{ABH}$ ke masyarakat. Penelitian ini memperlihatkan bahwa pemahaman pekerja sosial tentang konsep restorative justice masih lebih mengutamakan atau fokus pada aspek penyelesaian kasusnya.

Aprilianda, (2014) membahas mengenai pengkajian hukum tentang model pembinaan anak berbasis pendidikan layak anak dalam sistem pemasyarakatan. Setelah melakukan perbandingan di Malaysia, Thailand, Philipina dan Jepang, hasilnya merekomendasikan model pembinaan perorangan tidak murni (UnAbsolute Individual Treatment) yang memperhatikan aspek hukum, sosial, budaya, ekonomi dan psikologi Anak. Pada kasus-kasus tertentu pembinaan terhadap Anak dilakukan secara perorangan, misalnya pada tahap assessment, sementara untuk pembinaan anak dalam mendapatkan pendidikan bisa dilakukan melalui pendekatan kelompok dengan tetap memperhatikan kondisi Anak.

$$
\text { Harijanto dan Sunusi (2015) mengkaji }
$$
tentang pengembangan model alternatif menangani anak yang berhadapan dengan hukum berbasis masyarakat di kelurahan Cipinang, Jakarta Utara. Hasil penelitian ini memperlihatkan ada empat program yang dikembangkan antara lain: 1) sosialisasi kepada masyarakat dan anak, 2) manajemen kasus dan pemberian bantuan sosial anak, 3) membangun kelompok dukungan keluarga, dan 4) membangun kelompok dukungan sebaya. Proses penanganan berbasis masyarakat (community based) yaitu dilakukan dengan terencana, hal ini untuk memfasilitasi dan mengembangkan kapasitas individu, kelompok dan masyarakat guna merespon masalah-masalah yang ada. Pengembangan masyarakat sebagai strategi proses perubahan yang sistematis, terencana dan membebaskan kelompok yang puas dengan diri sendiri (pasrah), kehilangan atau mengalami depresi, penuh ketakutan serta kemiskinan, ke dalam kondisi masyarakat yang teratur penuh kesadaran, memiliki keberdayaan, penuh percaya diri, adil dan manusiawi.

Sholikhati dan Herdiana (2015: 464) menjelaskan bahwa orang tua dan Negara memiliki tanggung jawab terhadap $\mathrm{ABH}$. Peran orang tua dan negara memegang peranan vital untuk melindungi anak berkonflik dengan hukum secara fisik, psikis dan sosial. Dengan demikian analisis kami terhadap problematika ini akan menyangkut peran orang tua, yang meliputi: menjaga interaksi dan komunikasi yang hangat anak, agar anak terhindar dari perilaku kriminal; memberikan dukungan moral ketika anak melakukan tindakan kriminal, tidak menjauhi dan tidak melabel negatif; memberikan pendidikan nilai-nilai benar yang berlaku di masyarakat agar anak tidak bingung bagaimana tuntutan masyarakat terhadap dirinya sebagai individu. Peran negara meliputi: melindungi 
hak-hak anak; Optimalisasi restorative justice; Membangun pusat rehabilitasi untuk anak yang selama ini masih berkonsep 'penjara'; Meningkatkan sinergi yang kuat antara lembagalembaga penegak hukum, pemerintah, tokoh masyarakat untuk menangani anak berkonflik dengan hukum.

Menurut Sasmita (2015: 39) masalah utama bagi $\mathrm{ABH}$ bukanlah pada saat ia dipenjara atau ditahan dalam rumah tahanan, namun demikian yang lebih penting adalah pasca selesaianya hukuman. Urusan ini bukanlah pekerjaan mudah, sehingga dibutuhkan kerja sama keluarga, masyarakat dan pemerintah. Kerja sama tersebut dalam rangka segera memulai pola rehabilitasi dan reintegrasi agar menjadi sebuah sistem pemasyarakatan yang holistik dan integratif. Demikian pula diperlukan peningkatan frekuensi dan edukasi masyarakat tentang perlindungan anak sehingga dapat mengurasi stigma (labelling) bagi $\mathrm{ABH}$.

Sumarno dan Jayaputra (2015: 140) menyimpulkan $\mathrm{ABH}$ yang telah direhabilitasi secara psikologis dan ekonomi menunjukkan adanya perubahan sikap dan perilaku, yang semula suka minum minuman keras, penyalahgunaan obat, nongkrong, mencuri, melawan orang tua dan kenakalan lainnya sudah tidak tampak. Perubahan sikap tersebut diwujudkan dalam bentuk perilaku yang santun, sopan, ramah, hubungan dengan keluarga dan lingkungan baik. Anak-anak tersebut pasca rehab juga tidak meresahkan masyarakat lagi, bahkan dapat dijadikan contoh bagi anak- anak yang nakal, dan panti dapat dijadikan rujukan. Kemandirian eks penerima manfaat juga ditunjukkan dalam bentuk usaha yaitu jualan es, tambal ban, bengkel las dan membuka lapak sendiri yang semua kegiatan tersebut dapat membantu menopang hidupnya sendiri bahkan dapat membantu orang tua dan adik-adiknya dalam memenuhi kebutuhan hidup sehari-hari.
Husni (2015) mengkaji tentang penyelesaian masalah $\mathrm{ABH}$. Menurutnya sebelum imperialisme Belanda, bangsa Indonesia sudah memiliki hukum sendiri, yaitu hukum adat. Hukum adat tidak membedakan penyelesaian perkara pidana dengan perkara perdata, semua perkara dapat diselesaikan secara musyawarah dengan tujuan untuk mendapatkan keseimbangan atau pemulihan keadaan. Proses diversi atau pengalihan penyelesaian perkara dari peradilan formal kepada masyarakat akan berhasil antara lain, jika memberikan kesempatan bagi anak untuk rekonsiliasi atau reintegrasi dan penyembuhan dalam masyarakat yang dirugikan oleh tindak pidana.

Dari beberapa kajian tersebut di atas tampak bahwa persoalan $\mathrm{ABH}$ tidak hanya masalah hukum an sich, tetapi juga terkait dengan masalah ekonomi, psikologi, sosial, agama dan budaya. Karena itu kajian ini juga akan lebih difokuskan pada pendekatan budaya, sosial tentu juga agama. Sebab ketika membahas masalah adat Aceh, maka persoalan agama dan sosial tidak dapat dipisahkan.

\section{Dari Penjara Ke Rehabilitasi Sosial}

Ketika seorang $\mathrm{ABH}$ selesai menjalani pemeriksaan, proses pengadilan, dan akhirnya dijatuhi hukuman berupa penjara, maka anak tersebut akan berstatus narapidana. Dengan status narapidana tersebut, anak mendapatkan dampak buruk yang sangat memengaruhi hidupnya. Narapidana anak akan kehilangan kebebasan fisik, kehilangan kontrol atas hidup, kehilangan keluarga, kehilangan barang dan jasa, kehilangan keamanan, kehilangan hubungan heteroseksual, kurangnya stimulasi, dan gangguan psikologis. Dampak-dampak ini harus bisa diantisipasi atau bahkan dicegah agar anak tidak merasa tertekan dan menimbulkan dampak psikologis yang lebih besar lagi. 
Menurut laporan Komisi Perlindungan Anak Indonesia (KPAI) menunjukkan bahwa $80 \%$ anak yang masuk ke LAPAS pernah mengalami kekerasan. Seperti yang diungkapkan oleh buku yang berjudul "Cerita Anak dari Penjara (Pengalaman Pendampingan Anak dalam Penjara)", anak yang terlibat tindak pidana akan ditempatkan di sel tahanan dan penjara sejak pemeriksaan dan penyidikan, sampai adanya putusan pengadilan oleh hakim. Selama proses pemeriksaan, selain menerima kekerasan fisik, anak juga mendapatkan tekanan emosional dari polisi yang menangkap dan memeriksanya. Saat proses interogasi pun, ada anak yang dipaksa mengiyakan setiap pertanyaan polisi, bahkan jika sebenarnya jawabannya adalah tidak. Hal itu dilakukan karena anak tersebut menghindari pukulan dan tendangan dari polisi yang menginterogasinya (Solikhati dan Herdiana, 2015: 466).

Lingkungan Lapas yang seolah menjauhkan narapidana anak dari lingkungan luar dan dukungan sosial orang terdekat pun memberikan dampak buruk bagi anak. Lapas dapat mengakibatkan anak semakin rentan untuk mengalami kecemasan, perasaan tertekan, ketakutan, dan gangguan psikologis lainnya. Salah satu gejala psikologis yang sangat mungkin muncul selama menjalani masa tahanan adalah perasaan cemas (Herdiana, 2014). Jika orang dewasa saja merasakan kecemasan, apalagi anakanak yang masih memiliki kondisi psikologis yang labil. Kecemasan bukan hal yang mudah dikenali dan sering disebut sebagai ketidaknyamanan. Ketika seseorang merasa tidak nyaman, maka akan berdampak pula pada kondisi fisik, emosional, mental, dan spiritualnya. Perasaan cemas menyebabkan seorang anak menjadi gelisah, sehingga memunculkan perasaan negatif, dapat juga mengakibatkan mudah marah, ragu, panik, dan terteror. Lebih jauh lagi, secara mental seorang anak bisa memiliki pemikiran akan mati, dan merasa terasing. Salah satu kasus nyata, ada seorang anak yang berkonflik dengan hukum di Indonesia yang memilih untuk bunuh diri ketika berada di dalam tahanan karena tidak bisa menyesuaikan diri. Hal ini membuktikan bahwa anak memandang kehidupan penjara merupakan neraka yang sangat kejam, sehingga lebih baik mati daripada harus hidup di dalam penjara (Solikhati dan Herdiana, 2015: 467).

Selain itu dampak negatif yang ditimbulkan dari proses hukuman dialami oleh anak selain secara psikologis juga secara sosial. Setelah proses hukuman selesai, permasalahan anak tidak akan berhenti dengan sendirinya. Pemberian label (stigma) oleh masyarakat yang tidak baik kepada anak yang dijatuhi hukuman merupakan permasalahan tersendiri. Setelah keluar dari penjara, anak diasingkan oleh lingkungan sosial, lingkungan bermainnya dan lingkungan keluarganya. $\mathrm{Hal}$ itu dapat menyebabkan anak merasa sangat terasing dan terbuang dari lingkungan sosialnya. Kondisi yang demikian jauh dari terpenuhinya hak-hak anak. Hal demikian menunjukkan bahwa penjara bukanlah tempat yang baik bagi $\mathrm{ABH}$, perlu diupayakan alternatif lain untuk tetap mendukung proses tumbuh kembangnya anakanak $\mathrm{ABH}$ ini. Salah satunya bisa mendesain "penjara” yang "ramah bagi anak". Atau melalui proses pengalihan penyelesaian perkara anak dari proses peradilan pidana ke proses di luar peradilan pidana (diversi).

Apabila peradilan harus dilaksanakan, diharapkan hasilnya adalah memulihkan, bukan dijatuhkan hukuman pidana penjara. Anak yang berada di dalam lembaga juga harus terpenuhi hak-hak anak lainnya, seperti kesehatan, hak atas proses asimilasi dan hak berpartisipasi dalam kegiatan pembinaan berdasarkan ketentuan perundang-undangan yang berlaku. Pendekatan di luar institusi didasarkan pada data bahwa sebagian besar ABH di Jakarta 96\% masih memiliki orang tua. Di samping itu, diperlukan biaya yang tidak sedikit untuk mengembangkan 
pendekatan berbasis institusi. Inilah yang mendasari perlunya dikembangkan pendekatan di luar institusi yang berkeadilan atau restorative justice.

Anak pelaku tindak pidana sering kali dihadapkan pada proses peradilan formal yang dimulai dari penyidikan hingga menerima hukuman pidana yang diputus oleh hakim dan menjalani hukuman di lembaga permasyarakatan (LAPAS). Hal ini seharusnya tidak terjadi pada anak, karena pasca menjalani vonis, anak pidana mengalami tantangan besar dari masyarakat, yakni stigma. Pelabelan sebagai anak nakal, mantan napi memberikan tekanan tersendiri bagi mereka. Fasilitas yang mendukung tumbuh kembang anak juga masih terbatas seperti perpustakaan, tidak ada pendidikan formal, tidak ada fasilitas rekreatif, sanitasi minim, hukuman tidak mendidik bagi pelanggaran. Setelah itu mereka mengalami official designation yang dapat dilihat dalam fakta birokrasi atau aspek keperdataan. Seumur hidup mereka akan memiliki catatan kriminal dalam Surat Keterangan Kelakuan Baik (SKKB) dari kepolisian. Padahal jamak salah satu persyaratan kerja harus mencantumkan SKKB. Unofficial designation terasa dari sikap atau persepsi masyarakat terhadap mereka. Belum dapat menerima kehadiran anak yang pernah bermasalah hukum (Anwar, 2009).

Berdasarkan aturan hukum tersebut di atas bahwa $\mathrm{ABH}$ proses penyelesaiannya wajib dilakukan dengan diversi. Diversi adalah pengalihan penyelesaian perkara Anak dari proses peradilan pidana ke proses di luar peradilan pidana. Proses diversi tersebut anak juga wajib mendapatkan keadilan restoratif, yaitu penyelesaian perkara tindak pidana dengan melibatkan pelaku, korban, keluarga pelaku/korban, dan pihak lain yang terkait untuk bersama-sama mencari penyelesaian yang adil dengan menekankan pemulihan kembali pada keadaan semula, dan bukan pembalasan.
Selanjutnya kementerian sosial mengeluarkan peraturan No. 9 tahun 2015 tentang rehabilitasi sosial. Tujuannya agar $\mathrm{ABH}$ dapat melaksanakan keberfungsian sosialnya yang meliputi kemampuan dalam melaksanakan peran, memenuhi hak-hak anak, memecahkan masalah, aktualisasi diri, dan pengembangan potensi diri; dan tersedianya lingkungan sosial yang mendukung keberhasilan rehabilitasi sosial ABH. Berdasarkan aturan tersebut maka reintegrasi merupakan salah satu tahapan dari rehabilitasi sosial. Reintegrasi sosial dapat diartikan segala upaya yang ditujukan untuk menyatukan kembali anak dengan lingkungannya, baik lingkungan keluarga, sekolah dan masyarakat, maupun lingkungan anak lainnya, dengan membantunya menyesuaikan diri dengan lingkungan tersebut. Seseorang dapat berintegrasi dengan masyarakat apabila memiliki kemampuan fisik, mental dan sosial serta diberikan kesempatan untuk berpartisipasi (Kominfo dan Kemensos, 2012: 9).

\section{Karakteristik dan Penguatan Adat di Aceh}

Sebagai wilayah yang pertama mendapatkan cahaya Islam, masyarakat Aceh kental dengan warna agama. Menurut Hadi (2006: 19) ada tiga pola penyebaran Islam di kepulauan Nusantara, yaitu; integratif, dialogis, dan gabungan dialogis-integratif. Pola integratif, sebagian besar aspek kehidupan dan kebudayaan suatu komunitas diintegrasikan dengan pandangan hidup, gambaran dunia, sistem pengetahuan dan nilai-nilai Islam. Contohnya masyarakat etnik-etnik Melayu di Aceh, SumateraRiau, Banjar, pesisir Jawa seperti Banten, Jawa Timur dan Madura (Nurdin, 2016: 46).

Menurut Abdullah (2010: 129) dan Nurdin, (2015) masyarakat Aceh memiliki karakteristik tersendiri yaitu; Pertama, Aceh 
dikenal sebagai tempat dimana agama dan adat menjadi dua pilar penting dalam penataan sosial, sebagaimana disebutkan dalam dalam hadih maja (pepatah) yaitu; Hukom ngon Adat lagee zat ngon sipheut" (hukum [agama] dan adat bagai zat dan sifat, tak dapat dipisahkan) (Husein, 1970: 1). Kedua, orang Aceh dikenal sebagai pemberani yang mendapatkan pembenaran historis pada masa Perang Aceh. Aceh tidak mampu ditundukkan oleh penjajah Belanda, Portugis, Jepang sepanjang ratusan tahun disebabkan oleh "perang suci" atau "prang sabi" yang digelorakan oleh Teungku Chik Pante Kulu dalam naskah "Hikayat Prang Sabi” (Alfian, 1987). Ketiga, orang Aceh juga memiliki keyakinan dan kepercayaan diri yang tinggi disebabkan oleh adanya kebanggaan sebagai orang Aceh. Kebanggan ini tentu saja bersumber dari sejarah dan hikayat yang terus menerus dikomunikasikan dari generasi ke generasi. Keempat, orang Aceh menjunjung tinggi nilai-nilai kolektivitas. Hal ini tampak dari kebiasaan orang Aceh untuk berkumpul, dari fenomena warung kopi, saling kunjung, kenduri, serta upacara-upacara yang melibatkan banyak orang. Dalam kumpulan semacam ini, sosialisasi nilai keacehan dan identitas bersama dibangun, tumbuh melalui kesenian-kesenian. Seudati, Saman, Debus, dan berbagai tarian Aceh menegaskan ritme yang berorientasi kolektivitas.

Karakteristik inilah yang kemudian diperkuat kembali oleh pemerintah Aceh juga mengeluarkan Qanun No. 9 Tahun 2008 tentang Pembinaan Kehidupan Adat dan Adat Istiadat, yang berisi bahwa lembaga adat dapat menyelesaikan 18 perkara pada tingkat gampong yakni; 1) Perselisihan dalam rumah tangga; 2) Sengketa antar keluarga yang berkaitan dengan harta warisan; 3) Perselisihan antar warga; 4) Khalwat atau mesum; 5) Perselisihan tentang hak milik; 6) Perselisihan dalam keluarga; 7) Perselisihan harta seuharkat (gono gini); 8) Pencurian ringan; 9) Percurian ternak peliharaan; 10) Pelanggaran adat tentang ternak, pertanian dan hutan; 11) Persengketaan di laut; 12) Persengketaan di pasar; 13) Penganiayaan ringan; 14) Pembakaran hutan; 15) Pelecehan, fitnah, hasut dan pencemaran nama baik; 16) Pencemaran lingkungan; 17) Ancam mengancam; 18) Perselisihan-perselisihan lain yang melanggar adat istiadat.

Sacara yuridis qanun tersebut kemudian diperkuat oleh UU No. 11 Tahun 2006 tentang Pemerintahan Aceh. Kemudian pada tahun 2011 secara aplikatif disusul dengan Keputusan bersama antara Gubernur, Majelis Adat Aceh (MAA) dan Polisi Daerah Aceh tentang penyelenggaran peradilan adat gampong, mukim atau nama lainnya. Semua perkara tersebut dapat diselesaikan pada tingkat gampong melalui mekanisme peradilan adat, Keuchik bertindak sebagai hakim, dibantu oleh Tuha Peut dan Teungku Imum, Sekretaris gampong sebagai panitera. Jika masalah tidak selesai maka berperkara dapat diajukan ke imum mukim dan ini adalah majelis banding dan terakhir dalam tataran adat Aceh.

\section{Perlindungan Anak Berbasis Gampong di Aceh}

Gampong yang dipimpin oleh Keuchik (kepada desa) merupakan satuan pemerintahan terkecil di Aceh, di atasnya ada kemukiman dipimpin oleh Imum mukim. Sampai saat ini gampong tetap eksis, termasuk dalam membuat aturan-aturan hukum yang disebut reusam. Reusam perlindungan anak, beberapa gampong di Banda Aceh dan Aceh Besar telah membuat reusam (peraturan desa) tentang perlindungan Anak. Masyarakat didampingi oleh sebuah LSM yang bergerak di bidang pemberdayaan masyarakat dan perlindungan anak, Pusat Kajian Pendidikan dan Masyarakat (PKPM) bersama Restoratif Justice and Working Group (RJWG) didukung oleh Unicef. Beberapa gampong (desa) telah menerapkan proteksi terhadap $\mathrm{ABH}$, dengan cara memberikan hukum yang 
mendidik, karena pemberian sanksi menerapkan prinsip sebagaimana dijelaskan pada reusam gampong Pasal 10: 1) Bersifat mendidik bagi anak; 2) Mempertimbangkan usia anak dan bentuk pelanggaran yang dilakukan; 3) Tidak memberatkan anak dengan mempertimbangkan aspek psikologis anak; 4) Mengutamakan kepentingan terbaik bagi anak; 5) Bersifat pencegahan dan tidak memposisikan si anak sebagai pelaku kejahatan;

Mempertimbangkan prinsip keadilan bagi anak sebagai korban dan atau pelaku (Ridha dan Muhajir, 2015: 211).

Sedangkan jenis-jenis sanksi yang dapat diberikan yaitu; 1) Nasehat; 2) Teguran; 3)

Pernyataan permintaan maaf; 4) Denda; 5) Ganti kerugian; 6) Dikembalikan kepada keluarga dan masyarakat untuk pembinaan; 7) Tinggal di Dayah atau lembaga sejenisnya untuk belajar dalam beberapa waktu tertentu; 8) Membersihkan Meunasah atau Masjid atau fasilitas umum lainnya di Gampong; 9) Menjadi Mu'azzin di Masjid selama beberapa waktu tertentu; 10) Menghafal Juz 'Amma dalam jumlah tertentu. Sebagai catatan jika anak dipindahkan dari Gampong asal ke tempat lain yang lebih kondusif dan aman bagi anak karena pertimbangan tertentu dengan ketentuan tempat tersebut adalah keluarga, seagama, dan seadat. Pengenaan sanksi adat sebagaimana dimaksud pada ayat (2) dengan memperhatikan; Tingkat pelanggaran; Nilai keadilan; Kepatutan dan kelayakan berdasarkan kondisi anak dan keluarganya (Ridha dan Muhajir, 2015: 212).

Hal ini dipertegas oleh Ihsan Zakaria, aktivis LBH Anak dan kini aktif pendampingan dalam menyusun reusam gampong mengatakan bahwa beberapa kasus anak $\mathrm{ABH}$ sebagai pelaku pencurian potongan besi dan rokok di Aceh Besar. Kasus tersebut kemudian berhasil dilakukan diversi dan diselesaikan pada tingkat gampong, anak tersebut kemudian diberikan sanksi yang cukup mendidik yaitu membersihkan meunasah dan menjadi muazzin di Meunasah (mushallah) untuk beberapa waktu (Wawancara, 9 April 2017). Ditambahkan oleh Nurlaily, pengurus Puspelkesos Kecamatan Mesjid Raya, Aceh Besar, bahwa ada juga kasus pelecehan seksual yang dilakukan oleh anak terhadap beberapa anak lainnya. Kasus ini kemudian diselesaikan secara diversi dengan pendekatan adat. Pelaku dan korban didik dan dibina di dayah (pesantren) yang berbeda, saat ini mereka secara sosial dan psikologis sudah tidak ada masalah lagi (Wawancara, 10 April 2017).

Sejalan dengan itu, Firdaus Nyak Idin, Anggota Komisi Perlindungan Anak Aceh menjelaskan bahwa awalnya pembuatan reusam gampong tentang $\mathrm{ABH}$ mendapat penolakan dari pihak masyarakat terutama Keuchik (kepala Desa), Tuha Peut (semacam Lembaga Masyarakat Desa) dan Teungku Imum (Imam Desa), namun perlahan mereka dapat menerima karena pihak kami (PKPM-RJWG didukung oleh Unicef) menggunakan pendekatan adat dan budaya (Wawancara, 11 April 2017).

Ada catatan menarik dalam reusam gampong di Aceh adalah mengedepankan aspek pencegahan. Hal ini telah dilaporan oleh Unicef pada tahun 2012 dibeberapa daerah di Indonesia bahwa pada tingkat kabupaten, peraturan dan kebijakan tentang perlindungan anak cenderung berfokus pada permasalahan, terbatas pada rehabilitasi korban dan seringkali mengabaikan aspek-aspek pencegahan. Tidak adanya penetapan kewenangan yang jelas bagi pelayanan perlindungan anak di tingkat provinsi dan kabupaten menyebabkan aksi-aksi terfragmentasi dan kurang terkoordinasi. Pemerintah daerah tidak mengalokasikan anggaran yang memadai untuk perlindungan anak, dan kapasitas untuk implementasi secara umum lemah (Unicef, 2012: 2). 
Aspek pencegahan sebagaimana dilaporkan oleh Unicef tersebut jelas dapat diisi ruangnya oleh reusam gampong yang memang hadir untuk pembinaan anak misalnya dapat dilihat pada Bab IV tentang Peningkatan Kesadaran dan Upaya Pencegahan khususnya Pasal (5) tanggungjawab orang tua dan keluarga: (1) Keluarga menjadi tempat pendidikan dalam membentuk akhlakul karimah bagi anak; (2) Orang tua berkewajiban memberikan pendidikan yang baik bagi pertumbuhan dan perkembangan anak serta keteladanan yang baik dalam perkataan dan prilaku; kemudian Pasal (6) tentang tanggungjawab masyarakat bahwa masyarakat harus meningkatkan pendidikan bagi anak untuk belajar agama dan Al-Quran, membuat jam belajar Gampong; Perangkat Gampong dan masyarakat termasuk kaum perempuan harus ikut aktif berperan serta dalam pembinaan akhlak dan kesadaran hukum kepada anak; meningkatkan peran lembaga pendidikan informal (keluarga) dan nonformal seperti balai pengajian, meunasah (mushallah), dayah (pesantren); menyediakan sarana bermain dan olahraga anak; dan terakhir membentuk forum anak sebagai wadah organisasi anak.

Patut dicatat menurut Muslim Zainuddin, Direktur Pusat Kajian Pendidikan dan Masyarakat, bahwa reusam gampong merupakan bagian dari hukum adat dan kearifan lokal yang ada di Aceh yang kental dengan nilainilai Islam. Hukum Islam menurutnya juga mengedepankan aspek pencegahan, karena adat Aceh selaras dengan nilai-nilai Islam, makanya juga menonjolkan aspek pencegahan. Sebagai contoh gampong dampingan selain reusam juga mendorong gampong untuk membuat akta kelahiran anak, hal itu cukup penting untuk memberikan perlindungan dalam bentuk mengurus jaminan kesehatan atau beasiswa pendidikan. Selain itu, dalam konteks penyelesaian masalah, masyarakat Aceh menggunakan asas pendidikan dan perdamaian antar para pihak yang bersengketa (Wawancara, 17 April 2017).

\section{Penutup}

Pencegahan dan perlindungan $\mathrm{ABH}$ berbasis gampong di Aceh memiliki karakteristik tersendiri. Sebab beberapa gampong di Banda Aceh dan Aceh Besar telah memiliki reusam yang lebih mengedepankan pada aspek pencegahan dan perlindungan $\mathrm{ABH}$. Selain itu, dalam reusam tersebut peran serta masyarakat atau lembaga adat seperti keuchik, tuha peut dan teungku imum serta orang tua dalam melakukan pembinaan dan pendidikan anak menjadi aktor penting dalam program perlindungan $\mathrm{ABH}$. Pencegahan dan perlindungan $\mathrm{ABH}$ berbasis gampong di Aceh dapat menjadi lesson learn atau best practice yang dapat direplikasi di daerah lain di Indonesia. Sehingga anak-anak dapat menjemput masa depan lebih baik dan bermartabat.

\section{Daftar Pustaka}

Abdullah, Irwan. 2010. Konstruksi dan Reproduksi Kebudayaan, Yogyakarta: Pustaka Pelajar.

Alfian, Ibrahim, 1987. Perang di Jalan Allah: Perang Aceh 1873-1912, Jakarta: Pustaka Sinar Harapan.

Anwar, Yesmil. 2009. Saat Menuai Kejahatan, Sebuah Pendekatan Sosiokultural Kriminologi, Hukum, dan HAM. Bandung: Refika Aditama.

Aprilianda, Nurini. 2014. Laporan Akhir Pengkajian Hukum tentang Model Pembinaan Anak Berbasis Pendidikan Layak Anak dalam Sistem Pemasyarakatan, Jakarta: Badan Pembinaan Hukum Nasional Kementerian Hukum dan Hak Asasi Manusia.

Herdiana, Ike. (2014). Dampak Over Capacity di Lembaga Permasyarakatan Bagi Kesehatan Mental Narapidana, Dalam A. 
Chusairi, Bunga Rampai Psikologi Sosial: Catatan-Catatan dari Lapangan, Surabaya: Universitas Airlangga.

Hosein, Mohammad. 1971. Adat Atjeh, Banda Aceh: Dinas Pendidikan dan Kebudayaan Aceh.

Husni, 2015. Penyelesaian Anak Berkonflik dengan Hukum, Jurnal Nanggroe, Volume 4 Nomor 2 (Agustus 2015) Bagian Hukum Tata Negara Fakultas Hukum Universitas Malikussaleh.

Keputusan Bersama Gubernur Aceh, Kepolisian Daerah Aceh dan Ketua Majelis Adat Aceh, 2011. Tentang Penyelenggaraan Pelanggaran Peradilan Adat Gampong dan Mukim atau Nama Lainnya.

Kementerian Komuniksi dan Informasi dan Komenterian Sosial RI. 2012. Pedoman Opersaional Komite Perlindungan dan Rehabilitasi $A B H$, Jakarta: Dirjen Kesejahteraan Sosial dan Anak.

Kementerian Komuniksi dan Informasi dan Komenterian Sosial RI. 2012. Pedoman Kerja Antar Kementerian/Lembaga dalam Perlindungan dan Rehabilitasi Sosial ABH, Jakarta: Dirjen Kesejahteraan Sosial dan Anak.

Mery Ganti, 2012. Peran Pekerja Sosial Kementerian Sosial Republik Indonesia Dalam Penerapan Restorative Justice Bagi Anak Berhadapan Dengan Hukum Yang Dirujuk Ke Panti Sosial (Studi di Panti Sosial Marsudi Putra Handayani Jakarta Timur)

Nurdin, Abidin. 2015. Membangun Indonesia dari Aceh: Agama Pilar Pembangunan Sosial Budaya, Proceding Seminar Nasional: Membangun Indonesia Berbasis Nilai-Nilai Agama, 19-20 November, Universitas Airlangga Surabaya.

Nurdin, Abidin. 2016. Integrasi Agama dan Budaya: Kajian Tentang Tradisi Maulod dalam Masyarakat Aceh, Jurnal El Harakah, UIN Malang, Vol.18, No. 2.
Ota, Tatsuya. 1995. "Situasi Pembinaan Anak Nakal di Dalam Lembaga di Jepang, Pada Saat Ini”, dalam Pemasyarakatan Terpidana Anak dan Wanita Dalam Masyarakat Yang Sedang Membangun, Sponsor Masumoto Foundation-Japan, Depok: Universitas Indonesia.

Qanun No. 9 Tahun 2008 tentang Pembinaan Kehidupan Adat dan Adat Istiadat.

Ridha, M. dan Muhajir al-Fairusy. 2016. Modul Pelatihan: Penanganan $A B H$ melalui Mekanisme Peradilan Adat, Banda Aceh: Unicef, PKPM dan RJWG.

Sasmita, Dian. 2015. Sistem Pemasyarakatan dalam Kerangka Perlindungan Anak Berkonflik dengan Hukum, Jurnal Pascasarjana Universitas Negeri Semarang, Edisi 5 Jan-Jun.

Sholikhati, Yunisa dan Ike Herdiana, 2015. Anak Berkonflik dengan Hukum (ABH), Tanggung Jawab Orang Tua atau Negara?, Proceding Seminar Psikologi Kemanusiaan, Universitas Muhammadiyah Malang.

Sumaiya Khair, Karen L. Casper, Julia Chen, Debbie Ingram, and Riffat Jahan, 2000. Access to Justice: Best Practices under the Democracy Partnership, Dhaka: The Asia Foundation.

Sumarno, Setyo dan Achmadi Jayaputra, 2015. Kondisi Sosial Psikologis dan Ekonomi ABH Pasca Memperolah Rehabilitasi Sosial di PSMP Antasema, Magelang Jawa Tengah, Jurnal Sosio Konsepsia, Volume 4, Nomor 03, Mei-Agustus.

Undang-Undang Republik Indonesia Nomor 11 Tahun 2012 tentang Sistem Peradilan Pidana Anak.

Unicef Indonesia. 2012. Issue Briefs Child Protection, October.

Wismayanti, Yanuar Farida, 2013. Perdagangan Anak Perempuan yang Dilacurkan; Potret Suram Kemiskinan Versus Perlindungan Anak, Proceding Child Poverty and Social Protection Conference, Hotel Grand Sahid Jaya, Jakarta 10-11 September, Jakarta: Unicef, Bappenas, Kemensos dan Smeru. 